Smarter Growth 
The City in the Twenty-First Century

Eugenie L. Birch and Susan M. Wachter, Series Editors

A complete list of books in the series is available from the publisher. 


\title{
Smarter Growth
}

\section{Activism and Environmental Policy in Metropolitan Washington}

\section{John H. Spiers}

\author{
$\overline{\text { PENN }}$ \\ UNIVERSITY OF PENNSYLVANIA PRESS \\ PHILADELPHIA
}




\section{Copyright $\odot 2018$ University of Pennsylvania Press}

All rights reserved. Except for brief quotations used for purposes of review or scholarly citation, none of this book may be reproduced in any form by any means without written permission from the publisher.

Published by University of Pennsylvania Press Philadelphia, Pennsylvania 19104-4112 www.upenn.edu/pennpress

Printed in the United States of America on acid-free paper 1357791086642

\section{Library of Congress Cataloging-in-Publication Data}

Names: Spiers, John H., author.

Title: Smarter growth : activism and environmental policy in metropolitan Washington / John H. Spiers.

Other titles: City in the twenty-first century book series.

Description: 1st edition. | Philadelphia : University of Pennsylvania Press, [2018] | Series: The city in the twenty-first century

Identifiers: LCCN 2017056085 | ISBN 978-0-8122-5024-4 (hardcover : alk. paper)

Subjects: LCSH: Sustainable development-Washington Metropolitan Area-History20th century. | Economic development-Environmental aspects-Washington Metropolitan Area-History-20th century. | Environmental policy-Washington Metropolitan AreaHistory-20th century. | Environmental protection-Washington Metropolitan AreaHistory-20th century. | Environmentalism-Washington Metropolitan Area-History20th century.

Classification: LCC HC108.W3 S65 2018 | DDC 307.1/41609753-dc23

LC record available at https://lccn.loc.gov/2017056085 